\title{
Europeanization without substance? EU-Turkey relations and gender equality in employment
}

\author{
Ayșe İdil Aybars ${ }^{1} \cdot$ Paul Copeland $^{2} \cdot$ Dimitris Tsarouhas $^{3}$
}

(C) Macmillan Publishers Ltd., part of Springer Nature 2018

\begin{abstract}
This paper focuses on EU-Turkey relations through gender-related employment policy practices. We argue that Turkey is undergoing a process of 'Europeanization without substance', in which vague commitments and policy initiatives to enhance female labour force participation coexist uneasily with a contravening political discourse. This is not merely the result of a stalemate in accession negotiations, nor does it stem from the diversity of employment practices across the Union. It rather results from the deliberative discourses used by Turkey's political leadership to selectively appropriate certain aspects of Europeanization to further a politically motivated agenda that, in essence, negates gender equality altogether. This, we argue in turn, is reflected in a set of practices, policy initiatives, and public statements that make substantive progress in EU-Turkey relations harder. This process is facilitated by the diminishing emphasis placed by the EU on gender equality in employment as manifested by the evolution of gender equality practices at EU level and reinforced by austerity-led policies during the economic crisis.
\end{abstract}

Keywords EU-Turkey relations · Gender equality · Employment policy · Europeanization · Communicative discourse

Ayşe İdil Aybars

aybars@metu.edu.tr

Paul Copeland

p.copeland@qmul.ac.uk

Dimitris Tsarouhas

dimitris@bilkent.edu.tr

1 Department of Sociology, Middle East Technical University, Ankara, Turkey

2 School of Politics and International Relations, Queen Mary University of London, London, UK

3 Department of International Relations, Bilkent University, Ankara, Turkey 


\section{Introduction}

The literature on EU-Turkey relations through the prism of Europeanization mushroomed after Turkey became a candidate country in 1999 (Diez et al. 2005; Tocci 2005). Yet as Turkey's progress towards meeting the accession criteria stalled, doubts emerged as to whether Europeanization can 'lock in' positive conditionality leading to sustainable reform (Börzel and Soyaltin 2012; Sedelmeier 2012). More recently, talk of 'de-Europeanization' has emerged instead (Yilmaz 2015a; AydinDüzgit and Kaliber 2016). Despite the multifaceted nature of EU-Turkey relations and the salience of socio-economic standards in making EU accession a viable prospect, EU-Turkey relations have rarely been studied in the context of employment policy (but see Bolukbasi and Ertugal 2013; Tsarouhas 2012). The literature gap is particularly large regarding employment policy from a gender perspective, despite a sizeable literature in recent years on this issue in member states (Beveridge and Velluti 2008; Caporaso and Jupille 2001; Lombardo and Forest 2012).

Seeking to fill this gap, this paper examines EU-Turkey relations by considering gender equality in employment from a discursive institutionalist (DI) perspective. ${ }^{1}$ It assesses the extent and nature of Europeanization of gender equality in Turkey by examining the evolution of the political discourses on the issue since the start of the accession process. Turkey's track record with respect to women's rights has attracted much political debate over the last few decades despite rising incomes, in so far as the Global Gender Gap Index 2015 ranks Turkey 130th out of 145 countries. ${ }^{2}$ According to OECD data, Turkey's female employment rate stood at 30 per cent in 2014, compared to an OECD average of 58 per cent. A decade after the start of formal negotiations with the EU, it is time to ask: What has been the impact of Turkey's EU membership bid on gender equality in employment? What is the nature and extent of Europeanization in this policy area, and how has gender equality policy evolved in the EU during that time? Are there limits to Europeanization and if so, how can we account for them? Focusing on gender equality, the paper sheds light on the domestic political dynamics of the country, one of the key variables affecting the transfer of Europeanization practices to candidate countries.

We develop a twofold argument pertaining to both Turkey and the EU. First, we argue that Turkey is going through a process of 'Europeanization without substance', whereby vague commitments and policy initiatives to enhance female labour force participation coexist uneasily with contravening political discourses. This is not merely the result of a stalemate in EU accession negotiations or the (very real) diminishing importance attributed to gender equality. Rather, it results from the conscious decision by Turkey's political leadership and policy-makers to selectively appropriate certain aspects of Europeanization in order to further a politically

\footnotetext{
1 For the purposes of this study and notwithstanding alternative definitions, we define gender equality in employment to mean equal and unhindered access by women to the labour market to facilitate their financial emancipation and engagement in civic life as individuals equal to men.

2 World Economic Forum, Global Gender Gap Index 2015, available at http://reports.weforum.org/globa 1-gender-gap-report-2015/.
} 
motivated agenda that, in essence, negates gender equality altogether. This, we argue in turn, has its roots in the perception of the role of women in Turkish society and is reflected in a set of practices, policy initiatives and public statements. Second, Turkey's backsliding corresponds with a diminishing EU commitment to gender equality, which is manifested in its transformation over time to a 'weak' policy area.

In what follows, we begin with a brief discussion of our methodological and theoretical framework. The next section discusses EU-level developments on gender equality in employment, followed by an analysis of developments in Turkey over a fifteen-year period (divided into three sub-periods). The conclusion summarizes the main findings and spells out the implications of our case study for the use of Europeanization in gender-informed analyses of employment policy in candidate countries.

\section{Methodology: public communicative discourse}

This paper utilizes a public communicative discourse approach to systematically examine the way in which policy ideas interact with discourse, placing the emphasis on the use of ideas by policy actors (see also Hay and Rosamond 2002). Vivien Schmidt's discursive institutionalism (DI) (Schmidt 2008) sees discourse as 'the substantive content of ideas but also the interactive process by which ideas are spread' (Tsarouhas and Ladi 2013: 484). DI is made up of coordinative and communicative discourse. The former relates to the processes of creation, elaboration, and justification of programmatic ideas that actors use to convince each other and come up with a common language to set up a coherent programme (Schmidt 2002: 171). Coordinative discourse, on the other hand, focuses on ideas per se and, crucially for our purposes, is defined by the 'presentation, deliberation, and legitimation of political ideas to the general public' (Schmidt 2008: 310).

Following Lombardo and Forest $(2012,2015)$, we argue that the analysis of policy discourse allows us to trace the differential impacts of Europeanization in national settings, depending, inter alia, on the ways in which policy actors communicate their ideas to the public. Gender equality is a particularly interesting policy area to approach from such a perspective, in three respects. First, it is an area where, in addition to 'hard law', the EU relies on soft policy instruments, which specifically rests on the circulation of ideas and persuasion more than compliance (Beveridge 2012). Second, gender policy varies greatly across member states and candidate countries, because it is strongly embedded in different cultural/value systems and is most resistant to change due to long-established national traditions and institutional pathways. It thus presents an interesting test case to observe interactive processes of discussion, debate, and possible clashes between national and EU norms and discourses (Schmidt 2012). Third, gender equality is a policy area in flux, depending on the changing meanings attributed to gender and gender equality by policy-makers attempting to convince the public about the legitimacy of their chosen policy paths.

Several points need to be made to distinguish our attempt to examine the pathway of Europeanization of gender equality policy in Turkey from other studies on Europeanization. First, our paper focuses on communicative, rather than coordinative discourse. While the two are intertwined, coordinative discourse is largely missing 
from the Turkish policy-making scene, which is increasingly dominated by political leadership and its allies in academia and civil society. Policy-making is increasingly a top-down, unilateral process which does not feed from a diversity of views and actors. We therefore focus on how policy ideas are framed and communicated to the public with a view to demonstrating how gender equality discourse has evolved in relation to the EU and has been used by policy-makers through the three stages we discuss below.

Second, while Europeanization may indeed lead to divergent outcomes across different national settings, we further argue that, at certain times and in particular contexts, discourses can be used to dismantle the EU and to de-substantiate the Europeanization processes that had been undertaken. What we add to the relevant literature is an attempt to demonstrate that differential Europeanization can end up meaning 'Europeanization without substance' with particular national cognitive frameworks and traditional meanings attributed to gender equality.

Third, this study adopts an interactional approach to Europeanization in that it incorporates the EU discourse on gender equality in its analysis. This way, we hope to demonstrate that national policy discourses may use the lack of a consistent EU discourse on the issue as an opportunity to shape their own discursive practices.

\section{Europeanization and candidate countries}

The accession prospect of Central and East European Countries (CEEC) to the EU triggered the development of complex political and economic conditions which applicants now need to satisfy before becoming members (Gateva 2015; Grabbe 2002; Hughes et al. 2004; Schimmelfennig and Sedlemeier 2004, 2005). The 'conditionality' aspect of EU enlargement refers to the EU's ability to impose broader conditions in its role as a gatekeeper to membership. The process lasts a number of years, and EU funds are channelled to candidate states to ease the process of convergence with EU standards and absorb some of the shocks associated with membership. A failure to comply with EU rules can result in sanctions in the form of restrictions on the financial assistance as well as the eventual rejection or refusal to grant full membership. Conditionality has proved to be a powerful stimulant to align domestic policy with the EU in the context of the 2004, 2007, and 2013 EU enlargements. As Schimmelfennig and Sedlemeier (2004: 661) note, the desire of CEEC to join the EU, combined with the high volume and intrusiveness of the rules attached to membership, has allowed the EU an unprecedented degree of influence in the restructuring of domestic institutions. In fact, conditionality offers unprecedented opportunities for cross-cutting cooperation between civil society groups and organizations united in the goal of domestic reform. In the case of Turkey, cooperation between secularist and Islamist women's groups, previously unheard of, was made possible during a limited time period, due to the carrot of EU accession and the convergence of their aspirations with the relevant EU agenda.

The literature has identified Europeanization as a key approach to understand the impact of the EU during accession preparations. In candidate countries the mechanisms of Europeanization are evident in two dimensions: the hard mechanism refers 
to acquis implementation, while the second, soft mechanism relates to pressures to internalize the EU's normative codes of conduct and 'appropriate' policy behaviour (Schimmelfennig and Sedelmeier 2005). However, the EU has become an inconsistent actor during accession preparations. Evidence from recent enlargement rounds suggests that EU conditionality is a continuously shifting process depending on the acquis content, the policy area, the country concerned, and the political context (Hughes et al. 2004). To illustrate: on the eve of the 2004 enlargement, the Commission's Comprehensive Monitoring Report highlighted the remaining gaps in the overall preparedness of each accession state, yet membership was granted in all cases (Gateva 2015: 56-57). Regarding gender equality, the research by Galligan et al. (2007) found that despite becoming full EU members in 2004, the CEEC fell short of meeting the EU's gender acquis conditions. This is indicative of the superficial salience attributed by the EU to gender equality, but also reveals the highly political nature of accession.

\section{EU and gender equality}

The EU has developed a complex, hybrid system of governance to promote gender equality, combining traditional hard law and soft policy instruments, as well as a wide array of actors and financial mechanisms. By the mid-1990s, numerous directives had been adopted covering equality with regard to pay, working conditions, part-time work, self-employment, social security schemes, occupational pensions, the burden of proof in discrimination cases, protection of pregnant workers, equal treatment in access to goods and services, and parental leave (Walby 2004; Masselot 2007). ${ }^{3}$ Soft policy instruments have been used since the 1970 s, including Council and Commission recommendations and resolutions, and action programmes. Historically, these have been used to broaden the remit of the EU's competence when coordinated action is desirable. They covered issues such as the provision of childcare, sexual harassment, and the balanced participation of men and women in the decision-making process, which expanded the focus of the EU from its traditional labour market-related remit. Soft instruments were, therefore, preferred in areas of gender equality where it was difficult to reach agreement among member states due to the cultural embeddedness of the issue.

Since the mid-1990s EU gender equality policy has been addressed predominantly through the Open Method of Coordination, which was introduced in 1997 with the launch of the European Employment Strategy (EES). This intergovernmental process establishes EU-wide benchmarks in policy areas and requires periodic reporting of progress by the member states and the issuance of country-specific Recommendations by the Council/Commission in areas of policy weakness. Gender equality was placed 'at the heart of the emerging employment policy of the EU'

\footnotetext{
3 Many of these original directives have been clarified and brought together into one legal document and can be found in the EU Gender Equality Recast Directive on gender equality in employment and occupation (2006/54/EC). However, in other areas, such as equal treatment and social security (Directive $79 / 7 \mathrm{EEC}$ ), the original directive remains in force.
} 
(Villa and Smith 2013: 273) in the early phase of the EES, with its emphasis on tackling the gender pay gap, fostering reconciliation of work and family life and facilitating the return to work (Rubery et al. 2003); it incorporated the 'gender mainstreaming' mechanism in 1999 (Velluti 2012) and established EU-wide employment and childcare targets as part of the Lisbon Agenda. However, the emphasis on gender equality started to lose its visibility by 2005 with the relaunch of the Lisbon Strategy (Velluti 2012; Fagan et al. 2006), where employment policy was streamlined with economic policies. The subsequent Europe 2020 strategy adopted in 2010 resulted in a clear de-prioritization of EU gender policy (Smith and Villa 2010). Within the framework of the OMC, gender equality has been promoted mainly through quantitative targets, rather than qualitative measures. Along with a turn to the legislative framework in the most recent period, but this time, within a different cognitive framework that attaches gender equality to issues of justice and promotion of rights this quantitative focus has resulted in a 'de-substantiated' policy approach to gender equality.

Following Jacquot (2015), we trace this 'de-substantiation' in terms of the objectives, instruments, structures and actors, as well as the understanding, i.e. the cognitive framework, of gender equality, across three main stages. These reveal the reflections of the transformations of EU gender equality policy across the three stages of Turkish gender equality policy examined in the next section, which underline the diminishing salience of the policy at the EU level. In the first period that roughly covers the 1980s and 1990s, which Jacquot calls the 'exception model', the EU was considered to have built one of the most progressive systems of gender equality in the world (Hafner-Burton and Pollack 2000). It did so by imposing on its member states 'a range of norms and values that are higher than those in place in most countries' (Jacquot 2015: 175). This model was mainly regulatory, based on robust legislative instruments, as well as on financial mechanisms to add, albeit a limited, redistributive dimension. The approach to gender equality at the time was 'equal treatment', 'based on the concept of equal rights and implemented through the law' (Jacquot 2015: 3); it was complemented by 'equal opportunities', which is based on the concept of difference and promoted through positive action measures. The cognitive structure of EU gender equality policy in this first model can be described as pursuing 'equality within the market': while gender equality issues were mainly formulated through a 'curious equilibrium' between the 'market norm' and 'equality norm,' the latter was autonomous and 'had specific "exceptional" legitimacy to act and develop as long as it was within these limits' (Jacquot 2015: 177).

The second period, called the 'anti-discrimination model', covers the era from the mid-1990s to mid-2000s, during which the equality norm became increasingly subordinated to the market norm. Equality was no longer an objective in its own right, but became conceptualized as an instrument to achieve growth and competitiveness. The understanding of equality in this model was 'equality for the market' (Jacquot 2015: 177). Gender equality became increasingly subsumed under the more general anti-discrimination framework, along with age, race, disability, and sexual orientation, losing the autonomy and exceptionality it had previously enjoyed. At the same time, EU gender equality policy went beyond the sphere of employment, with gender equality getting its place among the missions and objectives of the EU in all 
its activities. 'Equal impact', based on the concept of gender and operated through gender mainstreaming, came to complement the understandings of 'equal treatment' and 'equal opportunities'. Gender mainstreaming thus became the new main instrument of EU gender equality policy of the time, implying a non-binding but incentive-based mechanism gradually taking over regulation and distribution.

Finally, the third stage, starting in the mid-2000s, is marked by economic and political crises that the EU has been undergoing; these have had serious repercussions for gender equality, having seen efforts to block its main texts and adoption of only minimum requirements (Jacquot 2015). This period is characterized by a 'rights model', whereby gender equality has lost its connections with the social policy domain and has become embedded in a broader framework of justice and rights' promotion. While this marks a return to the 'equal treatment' approach, gender equality no longer benefits from the same financial incentives it used to enjoy: this new conceptualization signals 'the end of the programmes specifically directed at women and gender equality in place since 1975' (Jacquot 2015: 147). Gender equality as a goal became secondary, able to develop only through small initiatives 'despite the market', under institutional structures that had to fight for their legitimacy and through interest groups competing with 'all the other organizations in the area of the defence of rights' (Jacquot 2015: 178), while activists and feminists have been marginalized in the policy-making process. This implies a 'dependent pluralism', 'a pluralism that encourages competition between civil society organizations whilst continuing to privilege certain amongst them' (ibid.: 166). In summary, the basis of EU gender equality policy has been continuously eroded over the last several years and is undergoing a dismantling process.

EU gender equality policy has thus been characterized by discontinuity and rupture, with 'changes in goals, means, ways of operating and ways of thinking' (Jacquot 2015: 178). In light of the three-phase analysis above, the following section examines Turkey's gender equality record in three periods, which, interestingly, overlap with the former in many respects.

\section{Gender equality in Turkey's EU accession process}

Gender inequality is deeply entrenched in Turkey's socio-economic and political structure (Aybars and Tsarouhas 2010). The subordinate position of women is generally accounted for by three principal explanations. The first underlines patriarchy in the country, which translates into a peculiar 'public equality' versus 'private inequality' nexus marked by the leading role given to women in the modernization and westernization process undertaken by the early Republic (Gunes Ayata and Tutuncu 2008). ${ }^{4}$ The second explanation underlines the impact of a particular amalgamation

\footnotetext{
4 Improving the position of women constituted one of the focal points of Turkey's modernization process. Women were given full political rights as early as $1930 \mathrm{~s}$, and their role as carriers of the modernization and westernization project was underlined. Gender equality, at least in the public sphere, was therefore a primary facet of Turkey's modernization objectives. Nevertheless, the patriarchal and protectionist understanding of the state was reflected in several legal provisions, which perpetuated gender inequality. Particularly, the Civil Code and Penal Code established the man as the head of the household', whereby a woman's decision to work was to be authorized by her husband or father. Moreover, provisions in social security arrangements made women dependent on their father or husband and tied
} 
Table 1 Employment and unemployment rates by sex in Turkey and the EU, 2000-2015 (in per cent). Source: Eurostat, http://ec.europa.eu/eurostat/web/ products-datasets/-/tesem010; http://ec.europa.eu/eurostat/web/ products-datasets/-/tesem 120

\begin{tabular}{|c|c|c|c|c|}
\hline \multirow[t]{2}{*}{ Year } & \multicolumn{2}{|c|}{ Employment } & \multicolumn{2}{|c|}{ Unemployment } \\
\hline & TR & EU & TR & EU \\
\hline 2000 & $26.2 *$ & $57.3 * *$ & $6.5^{*}$ & 9.9 \\
\hline 2005 & $22.3^{*}$ & 60.0 & $11.5^{*}$ & 9.8 \\
\hline 2010 & 28.0 & 62.1 & $13.3^{*}$ & 9.6 \\
\hline 2015 & 32.5 & 64.3 & $12.9^{*}$ & 9.5 \\
\hline
\end{tabular}

*Data on Turkey retrieved from OECD Statistics, http://www.oecd. org/employment/emp/employmentdatabase-employment.htm

**Data concern EU-27, before the accession of Croatia

of conservatism and neoliberalism (Bugra and Keyder 2006; Bugra 2014), leading to an emphasis on the family as the main social protection mechanism in the absence of a comprehensive welfare state (Dedeoglu 2012). The patriarchal conceptualization of women as mothers and caregivers translates into a conservative approach emphasizing women 'within the family' instead of as individual citizens. When coupled with neoliberal employment relations, this implies a practical impossibility for women to participate in the labour market (Bugra 2014). Indeed, the lack of public support for childcare is the top reason why women do not participate in, or eventually drop out of, the labour market (Korkut and Eslen-Ziya 2011). The third explanation focuses on political factors and argues that women's current position is the consequence of the long-standing intertwining of religion and politics in Turkish society (Arat 2010), which has gained new impetus in the last decade. Gender roles defined by religious references are increasingly adopted in the official discourse, which is reflected in a search for an alternative cognitive framework for policies that supposedly aim towards gender equality.

One of the most significant areas where gender inequality reflects itself in Turkish society, as stressed in the second point, is the labour market. Turkey has one of the lowest female employment rates among countries with similar levels of economic development, reaching only half of EU levels (61.4\% in 2017) and OECD averages (59.4\% in 2016) (Eurostat 2017; OECD 2017). Table 1 shows that, during the accession process of the country, female employment patterns for the 15-64 age group displayed significant fluctuations, hitting record lows between 2005 and 2010, then stabilizing at around $30 \%$ by the mid-2010s. While there are various explanations for declining female labour force participation rates in Turkey in contrast to global trends (see Aybars and Tsarouhas 2010), these point to the importance of the EU anchor regarding proactive policies in the field.

\section{Footnote 4 (continued)}

their social protection to the family's male members, considered the main breadwinners. Coupled with the weakness of the welfare state, these provisions established a social structure where the main role of women was to take care of family members and undertake domestic work (Gunes Ayata and Tutuncu 2008). 
Below we identify three periods accounting for Turkey's gradually declining levels of commitment to gender equality within the framework of its EU accession process, accompanied by types of communicative discourses that increasingly distance the country from the attainment of gender equality objectives.

\section{9-2007: 'gender equality': peak of Europeanization}

The first period, covering the immediate aftermath of Turkey's official recognition as an EU candidate country, was marked by a strong commitment to EU-led reforms. Turkey's trajectory of accession provided a window of opportunity for improving women's position. Though Turkey was already in a process where women's rights and gender equality were taken more seriously as of 1999 (Fougner and Kurtoglu 2015; Gedik 2015), the EU anchor was crucial in the expansion of women's rights, since it opened new channels of communication with European countries and civil society organizations (Arat 2010) and initiated steps advancing women's rights to comply with EU requirements. Successive governments of different political persuasions contributed to that, with the coalition government (comprising the left nationalist Democratic Left Party, the nationalist right-wing Nationalist Action Party, and the centre-right Motherland Party) of 1999-2002 initiating the process. That government introduced a new Civil Code in 2001, as well as the first major set of amendments to the Constitution in 2001 to speed up Turkey's timetable for EU accession. The amended Article 41 of the Constitution in 2001 established the family as based on equality between spouses. The new Civil Code in 2001 stated that spouses have shared authority to make decisions within and concerning the family.

After the 2002 election, the Justice and Development Party, having assumed office with a strong commitment to the EU accession process (Arat 2010), continued by introducing several legal amendments to harmonize legal practices with the EU acquis (Gunes Ayata and Tutuncu 2008). The Constitutional Amendment of 2004, a new Labour Law in 2003, and a new Penal Code in 2005 were all major steps undertaken with the aim to fulfil Turkey's EU-related obligations. In 2004, a clause was added to Article 10 of the Constitution providing that women and men have equal rights and that the state has the obligation to ensure this equality in practice. The 2003 Labour Law included measures such as the prohibition of gender-based discrimination in employment relations, the prevention of women's lawful dismissal on grounds of pregnancy, the extension of compulsory paid maternity leave from 12 to 16 weeks, as well as the introduction of a daily 1.5-h paid nursing leave for female workers with children below the age of 1 (Fougner and Kurtoglu 2015). A by-law in 2004 regulated the establishment of nursing rooms for workplaces employing 100-150 female employees, and of day-care nurseries for those employing more than 150 female employees. ${ }^{5}$ Moreover, a Prime Ministry Circular in 2004 promoted gender equality in the recruitment of civil servants (ibid.).

\footnotetext{
5 This is a widely debated measure as it is not effectively implemented and many work places do not hire women so as not to reach the numbers provided by the law. Moreover, the fact that the law explicitly states 150 female employees is questioned by feminist groups because it associates the role of caregiving with women (Bugra 2014; Korkut and Eslen-Ziya 2011).
} 
This period therefore introduced important legal changes in the position of women in line with EU accession requirements (Korkut and Eslen-Ziya 2011), 'from dependent citizens to more independent participants in society' (Dedeoglu 2012: 270). The importance of EU accession in the democratization process of the country, moreover, was strongly underlined by the political leadership, as the whole range of legal reforms was presented as the direct outcome of the accession process (TBMM 2001). In this context, political discourse on gender equality was embedded in the country's democratization objectives; for example, the then Prime Minister Bülent Ecevit addressed equality between women and men as 'the prerequisite of civilization and democracy' (Turkiye, 8 March 2000). This discourse did not fundamentally change when the JDP took office by 2002; for example, the then State Minister responsible for women, Nimet Çubukçu declared that the EU accession process was key to resolving women's problems (Bianet, 7 July 2006). The importance of international standards and the EU acquis was also highlighted by the then Prime Minister Recep Tayyip Erdoğan, when he stated in 2006 that "equality between men and women has finally obtained constitutional guarantee with the EU acquis and the steps taken to meet the Copenhagen political criteria', underlining that 'a society where women are not active is not complete' (Hurriyet, 8 November 2006).

This first period marks the 'peak of Europeanization' characterized by a communicative discourse stressing gender equality in line with the EU discourse. EU norms regarding gender equality are consistently taken as the main point of reference, and public statements underline the need to achieve EU standards as key to improving women's position. ${ }^{6}$ The whole range of legislative reforms contains direct references to the requirements of EU membership, while 'gender equality' appears as the major discourse adopted by policy-makers and communicated to the public.

\section{7-2011: women as 'mothers': weakening commitment to the EU}

The JDP secured a second term in 2007, increasing its vote share from 34 to 46 per cent. This second period is characterized by a weakening commitment to the EU membership bid, mainly due to the more confident attitude of the governing party, rooted in its electoral success, in proceeding with its own view of gender equality. While policy change as an outcome of Europeanization can still be observed during this period, the discourse employed by political leadership shifted decisively away from gender equality and towards women's role as mothers and standard bearers of 'family values'.

The most notable changes during this second period centred on combatting violence against women (Fougner and Kurtoglu 2015), sidestepping problems concerning women's labour market participation and dealing with women mainly within the private sphere. As for gender equality in employment, some legislative changes

\footnotetext{
${ }^{6}$ Nevertheless, some of the legal amendments that are beyond the focus of this paper (concerning the debate on increasing women's quotas and adultery discussions involved in Penal Code proposal, for instance) already witnessed JDP's recourse to religiously inspired references (Gunes Ayata and Tutuncu 2008).
} 
did occur, including the introduction of an incentive scheme for the government's five-year contribution to cover employers' social insurance premiums for women employed within a year; the extension of unpaid maternity leave from 1 to 2 years; the introduction of two years of unpaid paternity leave; and the extension of the daily nursing period from 1.5 to $3 \mathrm{~h}$ for the first 6 months following maternity leave. Furthermore, the Social Insurances and General Health Insurance Law in 2008 provided for the gradual equalization of the retirement age for both men and women (Fougner and Kurtoglu 2015). These legal arrangements point to the fact that, while not as strong as changes witnessed in the first phase, the Europeanization of gender equality in employment policies was still in force.

While the government's discourse continued to underline a vague commitment to increasing female employment, practical measures to achieve this were limited to the promotion of flexible work arrangements and female entrepreneurship (Bugra 2014). Gender-blind policy choices that did not involve any special measures to enable women to balance work and family life, particularly through the public provision of care services, reinforced women's traditional roles as mothers and caregivers, since it was increasingly difficult for women to participate in work under these conditions (Bugra 2014). Against the backdrop of legislative improvements in gender equality, the second period marked an inclination towards conservatism, whereby policy choices reflected the understanding of care work as women's exclusive responsibility. The increasing salience of conservatism in public life was effective in shaping 'a value universe where traditional views of gender difference [were] reasserted' (Bugra 2014: 152). The explicit policy choice to leave care matters to the family and women aligned perfectly with the neoliberal dictate of cutting back social expenditure.

In terms of the discursive aspect, the government started to express its conservative understanding of gender relations more boldly, advocating views that would confine women to the private sphere to fulfil traditional roles as good mothers and wives. The increasing emphasis on 'women as mothers' was backed by a political discourse about declining population levels, marriage at a later age, and changing family structures (Korkut and Eslen-Ziya 2011). This was visible in the then Prime Minister Erdoğan's insistence that women give birth to at least three children (Hurriyet, 7 March 2008), a statement he first made on International Women's Day in 2008 and repeated on several occasions. In the same vein, in a meeting organized with women's NGOs, Erdoğan declared that he 'did not believe in gender equality' and that women and men were different, complementary to each other (Vatan, 20 July 2010a). Conservative and patriarchal values on the family and the gender division of labour were at the centre of the government's communicative discourse: Erdoğan made repeated references to the family as 'the most sacred being, the building block of our society', where 'our fathers are called "the head of our households" and our homes are called "father's home", referring to traditional Turkish sayings (Milliyet, 16 May 2008). The then Minister responsible for women Çubukçu added 'the female bird builds the nest', pointing to the importance of women within the family and their role in raising children as 'building the foundations of strong families' (Bianet, 11 July 2008b). Despite the efforts of women's rights activists, the long-awaited Commission in Parliament on Gender Equality was established as the 
Parliamentary Commission on Equal Opportunities in 2009 (Bianet, 12 February 2009).

The conservative discourse stressing 'women as mothers' was further embedded in an increasingly nationalistic discourse, where the idea of the Turkish nation, as opposed to Turkey's European ideals, found stronger emphasis. In the 2008 statement mentioned above, Erdoğan underscored the need for families to have three children, due to the fact that 'there are those who desire to exterminate the Turkish nation' (Bianet, 10 March 2008a), e.g. in Europe, and juxtaposing Turkish society to the EU. This points to rising EU scepticism on the part of policy-makers, which became crystal clear towards the end of this second period. Following the 2010 adoption of constitutional changes via a referendum, the Turkish government started to openly question the sincerity of the EU in accession talks; it labelled the EU a 'Christian Club' and demanded to know whether Turkey would ever be given a clear accession timetable (Gulmez 2013). This is clear in Erdoğan's declaration: ‘...if you are not a Christian Club, you are obliged to take Turkey in' (NTV, 12 June 2010).

The second period offers significant evidence of a process of a 'weakening Europeanization', whereby government discourse on 'women as mothers' signalled an important departure from the cognitive bases of the EU gender equality policy. This, in turn, is directly related to the worsening relations between the two sides. Developments in Turkey went hand in hand with increasing scepticism among some EU member states as to the desirability of Turkish accession, even if the country were to fulfil all conditions. The accusations levelled by Turkish officials against the EU took place in a context marked by weakened EU credibility regarding the Union's sincerity in handling Turkey as a 'typical' candidate country (MacMillan 2013), which was complemented by the diminishing salience of gender-focused employment policy at EU level.

\section{1-2015: 'gender justice': Europeanization without substance}

By gaining almost 50 per cent of the popular vote in the 2011 elections, the JDP did more than verify its political dominance and its ability to reshape party politics (Gumuscu 2013). The party managed to increase its share of the vote for a third straight time, an unparalleled electoral success. Many leading party functionaries became convinced that the party could now speak on behalf of all people.

A series of governmental initiatives in this period point to two parallel developments: first, the state intensified its attempt to present a quantitative improvement in Turkish female employment, in line with the EES approach, while making sure that the incentive structure offered to female employees would keep them out of the public sphere. Second, Turkey's EU vocation suffered a heavy blow, as EU membership disappeared from the country's political radar. This was reflected in governmental discourse, challenging the EU on many occasions, including its social policy and gender equality norms.

A first major indication of things to come was the renaming of the Ministry for Women and Family Affairs as Ministry for Family and Social Policies in 2011, 
despite widespread opposition from women's organizations and feminist groups (Bianet, 8 June 2011). The loss of a specific focus on women (Eldem 2013) was a further sign that the definition of women's roles is subject to policy initiatives and statements commensurate with a deeply conservative understanding of their place in society. During this third period, women's roles again came under intense scrutiny, and earlier signs of a conservative/patriarchal approach reached unprecedented heights. ${ }^{7}$

In January 2015, the Turkish government announced its 'Programme for Protecting the Family and Dynamic Population', which ostensibly aimed at enhancing female employment despite the confirmation, through its title, of the disappearance of 'women' from the public agenda. The plan centred on a one-off 'Maternity Gift': the state would pay cash for the first three newborns of a couple $(300,400$, and 600 Turkish Liras for the first, second, and third, respectively). Second, parents could now be employed part-time until children attend primary school and be subsidized by the state depending on the number of their children. Finally, the government would supplement such payments with initiatives to facilitate access to affordable childcare (Munoz Boudet and Wiseman 2015).

Examining the plan in some detail reveals that the government's intentions remained firmly anchored to a conservative mindset. The plan omits references to the establishment of nurseries and affordable kindergartens. To enhance female employment it facilitates part-time female work, promoting flexibility in employment while offering women an extra burden: work part-time and take care of traditional family and household duties after work. Moreover, women's demand for paid parental leave was ignored (Dogan 2015). This programme perfectly encapsulates the two main elements that act as a driving force behind similar initiatives. First, whereas female employment is seen as desirable to enhance employability and growth, this cannot come at the expense of neglecting traditionally conceived gender roles in Turkish society. This is a crucial point: data confirm that women enter the labour force in Turkey upon graduation, but quickly leave it following marriage and starting their families (Fowler 2011). Second, attempts to open up more space for female employment can only materialize within an economic policy paradigm preoccupied with the need for flexibility at the expense of social and economic security.

More recent measures to increase female employment reinforce a traditional division of labour, underlining women's primary role as mothers 'to the point of making them unemployable', as illustrated by the government's pronatalist discourse, the idealization of the 'three generational family', and the introduction of social policy schemes encouraging home care (Fougner and Kurtoglu 2015: 157). As for the policy instruments employed to promote gender equality, the government is promoting 'family mainstreaming' rather than gender mainstreaming, an important element of the EU gender policy toolbox (ibid.).

\footnotetext{
7 Among the examples worth mentioning here is the suggestion in 2011 by the Supreme Council of Judges and Prosecutors that female rape victims could marry their rapists (NTV 2011) as well as the Health Ministry's statement a year later that children born because of rape could be 'taken care of' by the Ministry (Sol 2012).
} 
During this third period too, leading government officials declared their frustration with the alleged 'double standards' the EU uses against Turkey. In the process, they have not hesitated going as far as calling for the abandoning of EU membership as the country's strategic goal. Former Justice Minister Sadullah Ergin declared that it was likely that the EU would deny Turkey membership even if it met all conditions, at which point the two sides would part ways for good (Vatan, 20 November 2010b). Former EU Minister Egemen Bagis stated in 2013 that, if necessary, Turkey could tell the EU to 'get lost', not least because 'the EU needs Turkey' more than the other way round (Gardner 2013). Diminishing EU credibility reached its apogee in this third period, partly resulting from the Union's own stance. The refugee crisis and the declaration of a state of emergency following the attempted July 2016 coup emerged as further blows to EU-Turkey relations, intensifying the tensions; this led to explicit threats from both sides, of opening all borders and sending refugees to the EU on the part of Turkey, and of temporarily freezing membership talks on the part of the EU ( $B B C$ Turkish, 25 November 2016).

Developments over this last period point to Turkey's increasingly belligerent attitude towards the EU and its member states, a process that has heavily affected gender equality. The government started to express its regressive view of gender relations more overtly, this time backed by academic and policy circles, women's NGOs, civil society organizations that are close to the government, which, starting from 2014, used every platform to disseminate the idea of 'gender justice'. While the proliferation of actors in policy-making, particularly the involvement of women's organizations, appears to have been an important effect of Europeanization, these actors' close relations with the government indicate that this comes at the expense of excluding a wide array of oppositional actors from the policymaking process, reminding us of the concept of 'dependent pluralism' marking a recent weakening of EU gender equality policy (Jacquot 2015). A key example is the exclusion of feminist organizations from the formation of a national committee for monitoring the Istanbul Convention, only allowing for the participation of organizations approved by the government (Bianet 2014).

While 'gender justice' is a concept that is widely used in conjunction with 'gender equality', in the Turkish case, it turns out to be a concept that is now being used against gender equality (Gedik 2015). Accordingly, 'gender equality' is presented as a concept, grounded in 'Western' culture, forcing the masculinization of women. 'Gender justice' is distorted to emphasize the complementary character of the two sexes; it now refers to Islamic values to underline the 'different features and characteristics of men and women by nature', resulting in 'different functions and duties' (Yilmaz 2015b: 113): that men have to look after the family and protect women, while women must take care of children and household duties. Gender equality is rendered irrelevant, 'because women are “obviously" different from men' (Bugra 2014: 152). This is echoed strongly in Erdoğan's discourse, now the President, who stated, 'you cannot bring women and men to the same position, because it contradicts the creation' (fitrat): 'They talk about gender equality. What is right is equality of men to men; and equality 
of women to women. What is essential is equality of women within justice' (Milliyet, 24 November 2014).

The normalization of biological differences in terms of a 'natural' division of duties and functions between men and women now deliberately underlies policy choices. This is certainly at odds with the EU gender equality objectives and ideas (even if EU practices fall short), providing the grounds for our argument of 'Europeanization without substance'.

\section{Conclusion}

This paper focused on whether Turkey's EU vocation has had a discernible impact on gender equality in employment, as well as on the role played by the EU in shaping the process. To answer this question, we engaged with both the EU-level developments since the 1990s and Turkey's record of reforms. Methodologically, we focused on public communicative discourse and analysed the statements and positions adopted by senior policy-makers throughout this period. Theoretically, we employed the Europeanization framework and applied it to candidate countries through the prism of conditionality. Our main argument has been twofold. First, by use of a three-stage periodization we demonstrated the 'hollowing out' of Europeanization in Turkey's gender-related policy in employment. We find a gradual yet decisive shift in communicative discourse away from gender equality and towards a conservative mindset and policy practice influenced by functionalist necessities in the labour market, but always within the confines of a neoliberal economic paradigm combined, more recently, with the use of 'gender justice'. The result is 'Europeanization without substance'. Second, we link the trajectory of Turkey's dynamics to developments at EU level and its record on gender equality. Following Jacquot (2015), we argued that the Union's erstwhile treatment of gender equality as an exceptional policy area within the confines of the EU's marketdriven normative framework has steadily declined to a 'rights-based' model left vulnerable to competition from other rights' actors and having been decoupled from its social and employment policy connotations of an earlier era. The enlargement of 2004 underlined the diminishing salience of the gender acquis, while the recent economic and financial crisis has reinforced the existing dynamic, leading to forms of social downsizing that have had women, and working women as their largest victim. The findings of the paper point to the complex relationship between the EU, candidate countries, and the effects of Europeanization. While EU conditionality remains an important determinant for Europeanization in candidate countries, it also requires the necessary political will from both sides, in the absence of which even positive progress in a policy field risks being dismantled and de-Europeanized, particularly in strongly culturally embedded issues like gender equality.

Acknowledgements This paper stems from the 2015 Jean Monnet Workshop hosted by Dimitris Tsarouhas at Bilkent University and funded by the European Commission, Project No. 529070-LLP-1-2012-1-TR-AJM-CH. 


\section{References}

Arat, Y. 2010. Religion, Politics and Gender Equality in Turkey: Implications of a Democratic Paradox? Third World Quarterly 31(6): 869-884.

Aybars, A.I., and D. Tsarouhas. 2010. Straddling Two Continents: Social Policy and Welfare Politics in Turkey. Social Policy \& Administration 44(6): 746-763.

Aydin-Düzgit, S., and A. Kaliber. 2016. Encounters with Europe in an Era of Domestic and International Turmoil: Is Turkey a de-Europeanising Candidate Country? South European Society and Politics 21(1): 1-14.

BBC Turkish. 2016. Erdoğan'dan AB'ye: Daha ileri giderseniz, sınır kapıları açılır (From Erdoğan to EU: If You Go Further, Border Gates Will be Opened). 25 November. Available at: http://www.bbc.com/ turkce/haberler-turkiye-38103319.

Beveridge, F. 2012. 'Going Soft?' Analysing the Contribution of Soft and Hard Measures in EU Gender Law and Policy. In The Europeanization of Gender Equality Policies: A Discursive-Sociological Approach, ed. E. Lombardo, and M. Forest. London: Palgrave Macmillan.

Beveridge, F., and S. Velluti (eds.). 2008. Gender and the Open Method of Co-ordination: Perspectives on Law, Governance and Equality in the EU. Aldershot: Ashgate.

Bianet. 2006. Çubukçu Sonunda Kadın Örgütleriyle Görüştü (Çubukçu Finally Meets Women's Organizations). 7 July. Available at: https://bianet.org/bianet/kadin/81798-cubukcu-sonunda-kadin-orgut leriyle-gorustu.

Bianet. 2008a. Erdoğan: Kadınlar Doğurun: Türk Milletinin Kökünü Kazıyacaklar (Erdoğan: Women, Give Birth: They Will Exterminate the Turkish Nation'. 10 March. Available at: https://bianet.org/ bianet/toplumsal-cinsiyet/105451-erdogan-kadinlar-dogurun-turk-milletinin-kokunu-kaziyacaklar.

Bianet. 2008b. Bakan Çubukçu, Erdoğan'ın “Babalarımız Evin Direğì” Sözünü Kınamadı, Savundu (Minister Çubukçu did not Criticize Erdoğan's Statement "Our Fathers are the Head of Our Households", She Defended it). 11 July. Available at: https://bianet.org/bianet/siyaset/108283-bakan -cubukcu-erdogan-in-babalarimiz-evin-diregi-sozunu-kinamadi-savundu.

Bianet. 2009. Kadın Örgütleri Vekilleri Uyardı: Fırsat Değil, Eşitlik İstiyoruz (Women’s Organizations Warned MPs: We Want Equality, not Opportunity). 12 February. Available at: http://bianet.org/ bianet/toplumsal-cinsiyet/112529-kadin-orgutleri-vekilleri-uyardi-firsat-degil-esitlik-istiyoruz.

Bianet. 2011. Kadın Bakanlığı Kaldırıldı, Kadın Örgütleri Öfkeli (Ministry for Women Abolished, Women's Organizations are Enraged). 8 June. Available at: http://bianet.org/bianet/kadin/130585-kadin -bakanligi-kaldirildi-kadin-orgutleri-ofkeli.

Bianet. 2014. Kadın Örgütleri İstanbul Sözleşmesi Sürecinden Dışlanıyor (Women's Organizations are Excluded from the Istanbul Convention Process). 22 December. Available at: http://bianet.org/biane t/kadin/161002-kadin-orgutleri-istanbul-sozlesmesi-surecinden-dislaniyor.

Bolukbasi, H.T., and E. Ertugal. 2013. Europeanisation of Employment Policy in Turkey: Tracing Domestic Change Through Institutions, Ideas and Interests. South European Society and Politics 18(2): 337-357.

Börzel, T. and D. Soyaltin. 2012. Europeanization in Turkey: Stretching a Concept to Its Limits? Working Paper Series, No.36, Kolleg-Forschergruppe (KFG) "The Transformative Power of Europe" Freie Universität Berlin.

Bugra, A. 2014. Revisiting the Wollstonecraft Dilemma in the Context of Conservative Liberalism: The Case of Female Employment in Turkey. Social Politics 21(1): 148-166.

Bugra, A., and C. Keyder. 2006. The Turkish Welfare Regime in Transformation. Journal of European Social Policy 16(3): 211-228.

Caporaso, J., and J. Jupille. 2001. The Europeanization of Gender Equality Policy and Domestic Structural Change. In Transforming Europe: Europeanization and Domestic Change, ed. M.G. Cowles, J. Caporaso, and T. Risse. London: Cornell University Press.

Dedeoglu, S. 2012. Equality, Protection or Discrimination: Gender Equality Policies in Turkey. Social Politics 19(2): 269-290.

Diez, T., A. Agnantopoulos, and A. Kaliber. 2005. Turkey, Europeanization and Civil Society. South European Society and Politics 10(1): 10-15.

Dogan, Y.P. 2015. Activist: Government's Family Package Encourages Motherhood, not Employment. Today's Zaman. 16 March. Available at: http://www.todayszaman.com/monday-talk_activist-gover nments-family-package-encourages-motherhood-not-employment_375315.html.

Eldem, T. 2013. The End of Turkey's Europeanization? Turkish Policy Quarterly 12(1): 125-135. 
Eurostat. 2017. Employment and Activity by Sex and Age-Annual Data. Available at: http://ec.europ a.eu/eurostat. Accessed 31 March 2018

Fagan, C., D. Grimshaw, and J. Rubery. 2006. The Subordination of the Gender Equality Objective: The National Reform Programmes and "Making Work Pay" Policies. Industrial Relations Journal 37(6): 571-592.

Fougner, T., and A. Kurtoglu. 2015. Gender Policy: A Case of Instrumental Europeanization. In The Europeanization of Turkish Public Policies: A Scorecard, ed. A. Güney, and A. Tekin. London: Routledge.

Fowler, S. 2011. Women Still an Untapped Force in Turkey. New York Times. 4 May. Available at: http://www.nytimes.com/2011/05/05/world/middleeast/05iht-M05-WORK-WOMEN.html?_r=0.

Galligan, Y., S. Clavero, and M. Calloni. 2007. Gender Politics and Democracy in Post-Socialist Europe. Leverkusen Opladan (Budrich).

Gardner, D. 2013. Opinion: EU Shares Blame with Erdogan for Loss of Reform Zeal. Financial Times. 30 September. Available online at: http://www.ft.com/intl/cms/s/0/fb9f22ce-1eb1-11e3b80b-00144feab7de.html\#axzz3icIQUZDX.

Gateva, E. 2015. European Union Enlargement Conditionality. Basingstoke: Palgrave Macmillan.

Gedik, E. 2015. Toplumsal Cinsiyet Ana Akımlaştırmanın Türkiye'de Kadın Hareketi Üzerindeki Etkisi Ve Toplumsal Cinsiyet Adaleti Kavram1. Akademik Hassasiyetler 2(4): 209-228.

Grabbe, H. 2002. European Union Conditionality and the Acquis Communautaire. International Political Science Review 23(3): 249-268.

Gulmez, S.B. 2013. Explaining the Rise of Euroscepticism in the Turkish Political Elite. In Turkey and the European Union: Facing New Challenges and Opportunities, ed. F. Cengiz, and L. Hoffman, 102-120. London: Routledge.

Gumuscu, S. 2013. The emerging Predominant Party System in Turkey. Government \& Opposition 48(2): 223-244.

Gunes Ayata, A., and F. Tutuncu. 2008. Party Politics of the AKP (2002-2007) and the Predicaments of Women at the Intersection of the Westernist, Islamist and Feminist Discourses in Turkey. British Journal of Middle Eastern Studies 35(3): 363-384.

Hafner-Burton, E.M., and M.A. Pollack. 2000. Mainstreaming Gender in the European Union. Journal of European Public Policy 7: 432-456.

Hay, C., and B. Rosamond. 2002. Globalization, European Integration and the Discursive Construction of Economic Imperatives. Journal of European Public Policy 9(2): 147-167.

Hughes, J., G. Sasse, and C. Gordon. 2004. Conditionality and Compliance in the EU's Eastward Enlargement: Regional Policy and the Reform of sub-National Government. Journal of Common Market Studies 42(3): 523-551.

Hurriyet. 2006. Erdoğan: İslam dünyasında kadın olması gereken yerde değil (Women are not in the Position they Deserve in the Islamic World). 8 November. Available at: http://www.hurriyet.com. tr/erdogan-islam-dunyasinda-kadin-olmasi-gereken-yerde-degil-5398904.

Hurriyet. 2008. Erdoğan: En az üç çocuk doğurun (Erdoğan: Have at least Three Children). 7 March. Available at: http://www.hurriyet.com.tr/erdogan-en-az-uc-cocuk-dogurun-8401981.

Jacquot, S. 2015. Transformations in EU Gender Equality: From Emergence to Dismantling. New York: Palgrave Macmillan.

Korkut, U., and H. Eslen-Ziya. 2011. The Impact of Conservative Discourses in Family Policies, Population Politics, and Gender Rights in Poland and Turkey. Social Politics 18(3): 387-418.

Lombardo, E., and M. Forest (eds.). 2012. The Europeanization of Gender Equality Policies: A Discursive-Sociological Approach. London: Palgrave Macmillan.

Lombardo, E., and M. Forest. 2015. The Europeanization of Gender Equality Policies: A DiscursiveSociological Approach. Comparative European Politics 13(2): 222-239.

MacMillan, C. 2013. Discourse, Identity and the Question of Turkey's Accession to the EU: Through the Looking Glass. London: Ashgate.

Masselot, A. 2007. The State of Gender Equality Law in the European Union. European Law Journal 13(2): 152-168.

Milliyet. 2008. Başbakan Erdoğan: Biz bir aileyiz, kırgınlıklar olması doğal (Prime Minister Erdoğan: We are a Family, it is Natural to have Resentments). 16 May. Available at: http://www.milliyet. com.tr/basbakan-erdogan-biz-bir-aileyiz-kirginliklar-olmasi-dogal-siyaset-545122/.

Milliyet. 2014. Kadın ile erkeği eşit konuma getiremezseniz çünkü o fıtrata terstir (You Cannot Bring Women and Men to the Same Position Because it Contradicts Creation). 24 November. Available at: http://www.milliyet.com.tr/erdogan-batsin-bu-dunya/siyaset/detay/1974189/default.htm. 
Munoz Boudet, A.M. and W. Wiseman. 2015. Turkey's Important Balancing Act: Promoting Women's Empowerment in Turkey. The Globalist, 9 April. Accessed on 5 July 2015 under http://www. theglobalist.com/turkeys-important-balancing-act/.

NTV. 2010. Erdoğan: AB Hıristiyan Kulübü değilse... (Erdoğan: If the EU is not a Christian Club...). 12 June. Available at: http://www.ntv.com.tr/turkiye/erdogan-ab-hiristiyan-kulubu-degilse, $\mathrm{YgpH}_{-}$ 1DlnEuHRMwWwwGYkA.

NTV. 2011. Kadin tecavuzcusuyle evlensin (Women to Marry Their Rapists). 17 September. Available at: http://www.ntv.com.tr/turkiye/kadin-tecavuzcusuyle-evlensin,m_pzKI8kP06ZFIEjG5ljrg.

OECD. 2017. Employment Database—Employment Indicators. Available at: http://www.oecd.org/emplo yment/emp/employmentdatabase-employment.htm. Accessed 31 March 2018

Rubery, J., D. Grimshaw, C. Fagan, H. Figueiredo, and M. Smith. 2003. Gender equality still on the European agenda—but for how long? Industrial Relations Journal 34(5): 477-497.

Schimmelfennig, F., and U. Sedlemeier. 2004. Governance by Conditionality: EU Rule Transfer to the Candidate Countries of Central and Eastern Europe. Journal of European Public Policy 11(4): 495-518.

Schimmelfennig, F., and U. Sedelmeier (eds.). 2005. The Europeanization of Central and Eastern Europe. Ithaca: Cornell University Press.

Schmidt, V.A. 2002. Does Discourse Matter in the Politics of Welfare State Adjustment? Comparative Political Studies 35(2): 168-193.

Schmidt, V.A. 2008. Discursive Institutionalism: The Explanatory Power of Ideas and Discourse. Annual Review of Political Science 11: 303-326.

Schmidt, V.A. 2012. Foreword. In The Europeanization of Gender Equality Policies: A Discursive-Sociological Approach, ed. E. Lombardo, and M. Forest. London: Palgrave Macmillan.

Sedelmeier, U. 2012. Is Europeanization Through Conditionality Sustainable? Lock-in of Institutional Change after EU Accession. West European Politics 35(1): 20-35.

Smith, M., and P. Villa. 2010. The Ever-Declining Role of Gender Equality in the European Employment Strategy. Industrial Relations Journal 41(6): 526-543.

Sol. 2012. Tecavuze ugrayan dogursun gerekirse devlet bakar (Rape Victims Should Give Birth; If Necessary, the State Will Look After the Newborns). 31 May. Available at: http://haber.sol.org.tr/devle t-ve-siyaset/saglik-bakani-imama-uydu-tecavuze-ugrayan-dogursun-gerekirse-devlet-bakar-haberi.

TBMM (Grand National Assembly of Turkey). 2001. 21. Dönem, 4. Yasama Yıl1, 3. Birleşim. TBMM Tutanak Dergisi, Vol. 71, 3 October 2001.

Tocci, N. 2005. Europeanization in Turkey: Trigger or Anchor for Reforms? South European Society and Politics 10(1): 73-83.

Tsarouhas, D. 2012. Social Policy in the EU and Turkey: The Limits of Europeanization. In Europeanization and Turkey. A Case Sui Generis?, ed. C. Nas, and Y. Özer, 161-180. Aldershot: Ashgate.

Tsarouhas, D., and S. Ladi. 2013. Globalisation and/or Europeanisation? The Case of Flexicurity. New Political Economy 18(4): 480-502.

Turkiye. 2000. Başbakan Ecevit: Kadın-erkek eşitliği uygarlıktır (Prime Minister Ecevit: Gender Equality is Civilization). 8 March. Available at: http://www.turkiyegazetesi.com.tr/Genel/a48346.aspx.

Vatan. 2010a. Kadınla Erkek Eşit Olamaz! (Woman and Man Cannot be Equals). 20 July. Available at: http://www.gazetevatan.com/-kadinla-erkek-esit-olamaz-318006-siyaset/.

Vatan. 2010b. Adalet Bakanı AB'ye çıkıştı (Justice Minister Lashes at EU). 20 November. Available at: http://www.gazetevatan.com/adalet-bakani-ab-ye-cikisti-341655-siyaset/.

Velluti, S. 2012. Employment and the Lisbon Strategy. In The EU's Lisbon Strategy: Evaluating Success, Understanding Failure, ed. P. Copeland, and D. Papadimitriou, 88-110. London: Palgrave Macmillan.

Villa, P., and M. Smith. 2013. Policy in the Time of Crisis: Employment Policy and Gender Equality in Europe. In Women and Austerity: The Economic Crisis and the Future for Gender Equality, ed. M. Karamessini, and J. Rubery. London: Routledge.

Walby, S. 2004. The European Union and Gender Equality: Emergent Varieties of Gender Regime. Social Politics 11(1): 4-29.

Yilmaz, G. 2015a. From Europeanization to de-Europeanization: The Europeanization Process of Turkey in 1999-2014. Journal of Contemporary European Studies 24(1): 86-100.

Yilmaz, S.A. 2015b. A New Momentum: Gender Justice in the Women's Movement. Turkish Policy Quarterly 13(4): 107-115. 
Ayşe İdil Aybars is an Associate Professor at the Department of Sociology and Chair of the Social Policy Master's Program at the Middle East Technical University, Ankara. Her research and teaching focuses on social policy in the EU and Turkey, sociology of EU, and media studies. She has been involved in various research projects aiming to promote social inclusion and gender equality in Turkey.

Paul Copeland is a Senior Lecturer in Public Policy at Queen Mary University of London. His research and teaching focuses on the political economy of European integration, particularly with respect to the EU's competence in employment and social policy, and the UK's relationship with the EU. He has published in the leading journals of EU studies and Public Policy, and he is currently finalizing a monograph on the European Semester and the EU's social dimension (Routledge).

Dimitris Tsarouhas is an Associate Professor at the Department of International Relations, Bilkent University, and a Visiting Fellow at the BMW Center for German and European Studies, Georgetown University. His research focuses on European Political Economy, Public Policy and EU-Turkey relations. $\mathrm{He}$ is the co-editor (with Owen Parker) of Crisis in the Eurozone Periphery: The Political Economies of Greece, Spain, Portugal and Ireland (London: Palgrave MacMillan). 